\title{
Groundwater Flow and Tritium Transport Modeling at Kori Nuclear Power Plant 1 Site
}

\author{
고리 1발전소 부지 내 지하수 유동 및 삼중수소 이동 모델링 \\ Wook Sohn'), Soon-Hwan Sohn, Chul-Min Chon* and Kue-Yong Kim* \\ KHNP Central Research Institute, 1312 Gil, 70. Yuseongdaero, Daejeon \\ *KIGAM, Gwahang-no 92, Yuseong-gu, Daejeon 305-350 Korea \\ 손욱1), 손순환, 전철민*, 김구영* \\ 한수원중앙연구원 대전광역시 유성구 유성대로 1312 번길 70 \\ *한국지질자원연구원 대전광역시 유성구 과학로 92
}

(Received August 30, 2010 / Revised March 02, 2011 / Approved July 18, 2011)

\begin{abstract}
Nuclear power utilities should establish a site-specific groundwater monitoring program for early detection of unplanned radioactive material's releases which can occur due to degradation of systems, structures and components of the nuclear power plants in order to keep the impact of the unplanned releases on the environment and the residents as low as reasonably achievable. For this end, groundwater flow on site should be evaluated based on characterization of the hydrogeology of a site of concern. This paper aims to provide data necessary for establishing groundwater monitoring program which is currently considered at Kori nuclear power plant 1 by characterizing groundwater flow system on the site based on the existing hydrogeological studies and related documents, and by modeling tritium transport. The results showed that the major groundwater flow direction was south-west and that most of groundwater entered a southern and eastern seas. Although the tritium plume also released into the sea, its rate was delayed by dewatering sump.
\end{abstract}

Key words : Unplanned Release, Groundwater, Tritium, Monitoring, Modeling

\section{요 약}

원전 운영자는 계통 및 기기의 열화 등에 의해서 발생할 수 있는 비계획적 방사성물질의 방출로 인한 환경 및 주변 주민에의 영향을 합리적으로 달성 가능한 한 낮게 유지하기 위해서 비계획적 방출을 조기에 감지할 수 있는 부지에 적합한 지하수 감시 프로그램을 수립해야 하며, 이를 위해서는 해당 부지의 수문지질 특성의 파악을 통해 지하수 유동을 평가해야 한다. 본 논문에서는 고리 1호기에서 계획되고 있는 지하수 감시 프로그 램에 필요한 자료를 제공하기 위해, 고리 1 발전소 부지의 기존 수문지질 조사 및 관련 자료의 조사를 통해 부 지 내 지하수 유동특성을 파악하고 이를 바탕으로 가상의 비계획적 방출에 의한 삼중수소의 오염운(污染雲) 의 거동을 모의하였다. 모의 결과 지하수의 주 유동 방향은 남서방향이었으며 지하수의 대부분이 남쪽 및 동

1) Corresponding Author. E-mail : wsohn@khnp.co.kr 
쪽 바다로 유입되었다. 삼중수소 오염운 역시 바다로 향하였으나 지하집수조(dewatering sump)에 의해 그 속도가 지연되는 것을 확인할 수 있었다.

중심단어 : 비계획적 방출, 지하수, 삼중수소, 감시, 모델링

\section{I. 서 론}

원자력발전소의 운영기술지침서에서 원전 가동에 의해 발 생하는 방사성물질의 일부를 감시 하에서 사전에 정해진 경로 를 통해 배출하는 것이 허용되고 있으며, 이를 계획적 방출 (planned release)라고 한다. 이러한 계획적 방출에 의해 환경 으로 배출되는 방사성물질의 양은 매우 적으나 방출된 방사성 물질이 환경과 원전 주변 주민에게 바람직하지 않은 영향을 줄 수 있기 때문에 원전 운영자는 계획적 방출에 의한 영향을 합리적으로 달성 가능한 한 낮게 (As Low As Reasonably Achievable, ALARA) 유지해야 한다. 즉, 원전 운영자는 방사 성물질의 방출(a)을 정해진 절차에 따라 실시하고 원전 주변 지 역의 환경 감시를 통해 방출된 방사성물질에 의한 원전 주변 주민의 피폭선량을 평가해야 한다.

최근 미국을 중심으로 한 해외의 여러 폐로 원전 및 가동 원 전에서 방사성물질이 정해진 경로 이외의 경로를 통해 방출된 사실이 발견되었는데 방사성물질이 원전의 계통 및 기기에서 발생한 누설 혹은 유출에 의해서 지하수로 유입되어 최종적으 로는 지하수와 함께 환경으로 도달하였다[1]. 비계획적 방출 (unplanned release)이라고 불리는 이러한 방출은 계획적 방 출과 달리 정해진 경로를 통한 방출이 아니기 때문에 방출에 대한 감시 및 관리가 어려우며 또한 운영기술지침서에서 허용 되고 있지 않은 만큼 그 발생을 미연에 방지해야 한다. 그러나 그 발생 원인이 주로 계통 및 기기 노후화에 의한 누설인 만큼 완벽한 방지가 어려우므로 신속한 대응을 위한 조기 감지가 중요하다. 이러한 비계획적 방출에 대한 조기 감시는 ALARA 측면에서 뿐만 아니라 최근 들어 미국 원자력규제기관이 요구 하고 있는 원전 가동 기간 중의 부지 내 잔류방사능 관리 측면 에서도 중요하다.(b) 이에, 현재 미국의 모든 원전 운영자는 자 발적으로 이러한 비계획적 방출을 조기에 감지하여 지하수를 보호하기 위한 내부지침[2]을 수립하고, 이에 근거한 지하수 감시 프로그램을 실시하고 있다. 지하수 감시 프로그램에서 지하수 오염 여부를 감시하기 위한 관정의 설치는 필수적이며 이 설치를 위해서는 원전 부지의 수문지질학적 특성에 근거하 여 지하수의 유동 방향을 파악하는 것이 필요하다.

우리나의 경우 누설 등의 비계획적 방출의 조기 감시 목적
으로는 경주 중저준위 방사성폐기물 처분장 내 지하수 유동 에 관한 연구[3, 4, 5]가 수행된 적은 있으나, 가동 원전에 대 해서는 거의 없는 실정이다. 본 논문은 고리 1 발전소에서 시 행 예정인 지하수 감시 프로그램 수립에 필요한 자료를 제공 하기 위해, 해당 부지 내 지하수의 유동 방향을 기존 문헌 및 자료를 통해 평가하고 누설 발생 시 예상되는 방사성물질의 오염물질의 확산, 즉 오염운(污染雲, plume) 거동을 모사하는 것을 목표로 하였다. 해외 원전의 모든 비계획적 방출 사례에 서 삼중수소는 오염된 지하수에서 검출되었으며, 또 삼중수 소가 물의 구성성분으로 지하수와 함께 이동하여 다른 핵종 보다 지하수 거동을 매우 잘 반영하는 점과 반감기가 12.3 년 으로 추적이 유리하다는 점을 들어 모사할 오염물질로 선정 되였다.

\section{II. 고리 1 발전소 수문지질 특성}

\section{가. 발전소 부지 개요 및 관정}

1978년과 1983년에 각각 건설된 고리 1,2 호기가 나란히 위치한 고리 1 발전소의 구조물은 건설 당시 해수면 이하까 지 굴착된 지반 위에 위치하고 있다. 즉 격납건물은 $\mathrm{EL}-20 \mathrm{~m}$, 보조건물은 EL-17 m 까지 굴착된 암반 위에 설치된 후 그 주 변부는 매립되었고 기타 구조물 및 지중매설배관 등은 EL -1 $\mathrm{m}$ 에 설치 된 후 매립되었다. 특히 격납건물 및 보조건물은 그 하부에 투수층이 깔렸으며 격납건물 남단에는 지하수 수 위 상승에 의한 구조물 안전 상실 방지 목적으로 지하집수조 (dewatering sump)와 펌프가 설치되어 강제 배수가 가능하 도록 하였다. 격납건물 등 주요 구조물 주변은 대부분 포장되

(a) 본 논문에서 영어의 release, leak 및 spill에 각각 해당하는 방출, 누 설 및 유출은 다음과 같은 의미로 사용되었다 즉, 방출은 원전 내부 에서 외부로 나오는 방사성물질의 총칭이며, 누설은 계통 및 기기 등에 발생한 틈새와 같은 결함에 의해 외부로 나오는 것을, 그리고 유출은 일시적 비정상 운전 및 조작에 의해 외부로 나오는 것을 의 미한다.

(b) 미국 원자력규제기광인 US Nuclear Regulatory Committee는 발전 소 가동에 따른 오염 물질 발생의 최소화를 그 내용으로 하는 연방 법인 10 CFR 20.1406 "Minimization of Contamination"의 지침에 해당하는 Regulatory Guide 4.21 "Minimization of Contamination and Radioactive Waste Production: Life-Cycle Planning"을 2008 년 6월에 공표하였으며, 이 지침은 원자력발전소의 건설부터 폐로에 이르는 모든 단계에서 방사성폐기물의 발생량을 최소화할 것을 요 구하고 있다. 
어 있으며 서남쪽 부지 경계와 스위치 야드, 경사면 등은 포 장되어 있지 않다.

고리 1 호기 계속운전 승인 조치의 일환으로 해당 부지의 수문지질학적 특성에 대한 이해를 증진시키기 위하여 2007 년에 고리 1 발전소에 5 개의 관정이 설치된 후(Fig 1), 최근까 지 이들 관정에서 정기적으로 지하수를 채취하여 수위, 수온 및 전기전도도가 측정되고 있다 [6].

\section{나. 지질}

고리 1 발전소 부지는 원래 봉화산 자락이 해안으로 뻗어나 간 부분으로 해발고도 $10 \mathrm{~m}$ 이상인 지역이었으나 부지조성 을 위해 해발고도 $5.8 \mathrm{~m}$ 까지 절토되고 서쪽 해안과 남쪽 해 안 인근은 성토되었다. 고리 원자력발전소 부지는 중생대 백 악기 초 퇴적암류(사질석회암, 실트암, 역암 및 조립질 사암) 가 대략 주향 $\mathrm{N} 30^{\circ} \mathrm{E}$, 경사방향 $\mathrm{NW}$, 경사각은 $10^{\circ} \sim 35^{\circ}$ 로 분 포되어 있으며, 이 퇴적암류에 중기 및 후기 백악기의 관입암 맥이 거의 수직방향으로 관입 - 분포하고 있다. 2007년에 설 치된 5 개 관정의 시추주상도 조사결과를 보면(Fig. 2), 비교 적 얇게 분포하는 상부 매립 및 붕적층은 자갈과 전석이 혼재 되어 이로 인해 공극이 발달하여 비교적 투수성이 매우 높다. 암반층은 셰일, 이암, 사암, 유문암 및 안산암 등의 암종에 따 른 다양한 투수성의 지층으로 구성되었으나, 암반층의 절리 와 발달된 파쇄대로 동일 암종의 일반적인 암반구간에 비하 여 투수성은 비교적 높게 나타났다.

\section{다. 수문 \\ (1) 수리전도도}

싱클패커(single packer) 방식의 수압 시험으로 결정된 관 정 NO-2 및 관정 NO-4 주변지층의 수리전도도는 각각 1.03 $\times 10^{-4} \mathrm{~cm} / \mathrm{sec}$ 및 $6.53 \times 10^{-6} \mathrm{~cm} / \mathrm{sec}$ 이었다. 5 개의 관정 중 4 개의 관정에 대해 수행된 순간수위변화시험에서 수리전도도

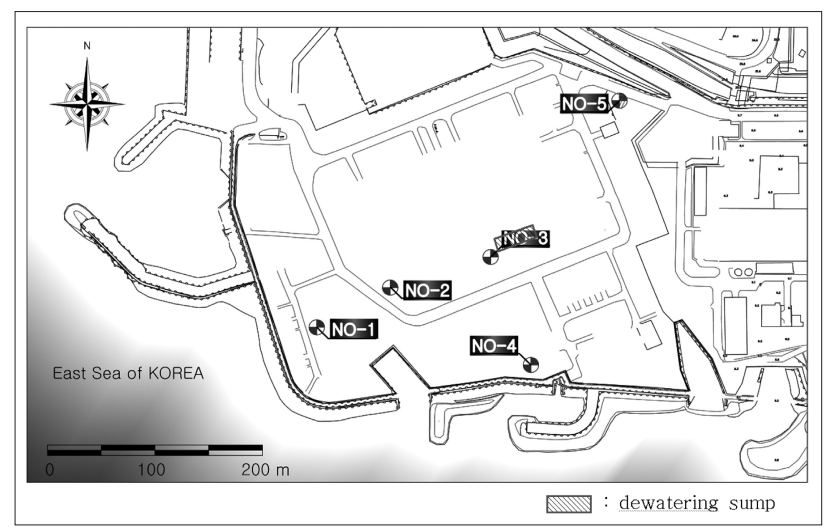

Fig. 1. Layout of wells installed at Kori Units 1 and 2 [6].
는 관정 NO-1에서 $7.07 \times 10^{-5} \mathrm{~cm} / \mathrm{sec}$, 관정 $\mathrm{NO}-2$ 에서 $6.67 \times$ $10^{-6} \mathrm{~cm} / \mathrm{sec}$, 관정 NO-3는 $1.04 \times 10^{-4} \mathrm{~cm} / \mathrm{sec}$ 그리고 관정 $\mathrm{NO}-5$ 에서 $1.01 \times 10^{-5} \mathrm{~cm} / \mathrm{sec}$ 이었으며 부지 전체의 평균 수리 전도도는 $4.80 \times 10^{-5} \mathrm{~cm} / \mathrm{sec}$ 로서 일반적인 사암 및 셰일의 수 리전도도 값의 범위에 들었으나 관정 NO-3에서 수행된 결과 는 투수성이 비교적 높은 값을 보였다(Table 1)[7].

관정 NO-2의 경우, 수압시험결과와 순간충격시험의 결과 사이에 15 배 이상의 차이가 발생하여 시험방법에 따른 투수 성의 차이가 다소 크게 나타났다. 이는 수압시험시 시추공 굴 진과 함께 이루어지기 때문에 관정주변 지하수위가 안정되지 않은 상태에서 시험이 이루어져 순간충격시험 결과와 다르게 나타난 것으로 추정된다. 수치모의시 입력자료는 순간충격시 험 결과값을 활용하였습니다.

\section{(2) 지하수 수위}

2007.8.1 2008.10.9 기간(14개월)에 걸쳐 5개 관정에서 지하수 수위를 자동으로 측정하였으며 그 결과를 Fig. 3에 나 타내었다[6]. 지하수 수위 변화는 가장 내륙에 위치한 관정 $\mathrm{NO}-5$ 는 강우와 함께 지하수 수위가 같이 반등하는 전형적인 지하수 수위 변화를 보였으며, 해안가에 위치한 관정 NO-4는 강우 대신 조석의 영향으로 하루에 최대 약 $0.9 \mathrm{~m}$ 의 수두차 를 보였다. 고리 1호기 바로 서쪽에 위치한 관정 NO-2는 지 하수 수위가 강우 영향을 약간 받는 양상을 보였으나 관정 $\mathrm{NO}-5$ 에 비해 수위변화가 크지 않았다. 고리 1호기와 2호기 사이에 위치한 관정 NO-3의 경우는 지하수 수위가 거의 EL $3 \mathrm{~m}$ 로 일정하게 유지되고 있었는데 이는 EL -20 m 부근에 설

Table 1. Results of hydraulic conductivity experiments by well (unit: cm/sec) [7]

\begin{tabular}{|c|c|c|c|c|c|}
\hline 곽정 방법 & NO-1 & NO-2 & NO-3 & NO-4 & NO-5 \\
\hline Single Packer & - & $1.03 \times 10^{-4}$ & - & $6.53 \times 10^{-6}$ & - \\
\hline Slug Test & $7.07 \times 10^{-5}$ & $6.67 \times 10^{-6}$ & $1.04 \times 10^{-4}$ & - & $1.01 \times 10^{-5}$ \\
\hline
\end{tabular}

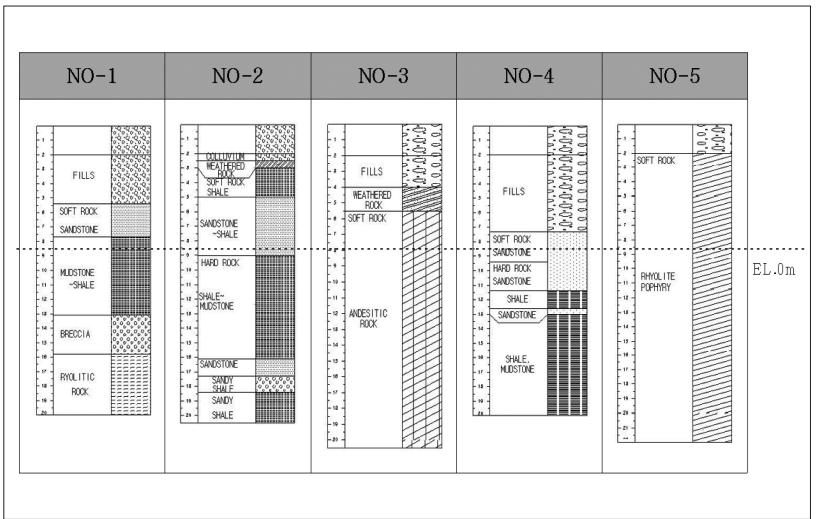

Fig. 2. Boring Logs from wells at Kori Units 1 and 2 [6]. 
치된 지하집수조에 의해 수위가 강제로 강하되어 일정 수위 이상 상승되지 않도록 양수되고 있었기 때문이다. 서쪽 해안 가에 위치한 관정 NO-1의 경우 지하수 수위가 해수면 근처로 낮지만 EL $-0.5 \mathrm{~m}$ 내외이며 강우와 조석에 의한 수위변동은 그리 크지 않다. 관정 NO-2와 관정 NO-3의 경우 2008년 하 반기에 계측오차로 추정되는 수위 변화가 관측되었기 때문에 모델링에서는 6개월의 건기(2007.11 2008.4) 기간의 수위자 료만을 활용하였다. 각 관정에서 관측된 지하수 수위 측정 결 과는 Table 2와 같다[7].

Table 2. Summary of groundwater level measurements by well [7].

\begin{tabular}{|c|c|c|c|c|c|}
\hline 봔정 & NO-1 & NO-2 & NO-3 & NO-4 & NO-5 \\
\hline 전쳉법 평균 지하수위(GL- m) & 5.84 & 3.04 & 8.47 & 4.99 & 3.33 \\
\hline 전체 평균 지하수위(EL m) & 0.06 & 2.76 & -2.77 & 0.71 & 5.27 \\
\hline 최저 지하수위(GL- m) & - & - & - & 5.80 & 4.24 \\
\hline 최고 지하수위(GL- m) & 5.61 & 2.23 & 7.60 & 4.29 & 1.92 \\
\hline 최대-최소 변화량(m) & - & - & - & 1.51 & 2.31 \\
\hline $\begin{array}{c}\text { 갈수기 평균수위(GL- m) } \\
(2007.11 ~ 2008.4)\end{array}$ & 5.88 & 3.13 & 8.54 & 5.01 & 3.40 \\
\hline $\begin{array}{c}\text { 풍수기 평균수위(GL- m) } \\
(2008.5 ~ 2008.10)\end{array}$ & 5.82 & 2.99 & 8.44 & 4.97 & 3.27 \\
\hline 갈수기-풍수기(m) & 0.06 & 0.14 & 0.10 & 0.04 & 0.13 \\
\hline 관측공 표고(EL m) & 5.9 & 5.8 & 5.7 & 5.7 & 8.6 \\
\hline
\end{tabular}

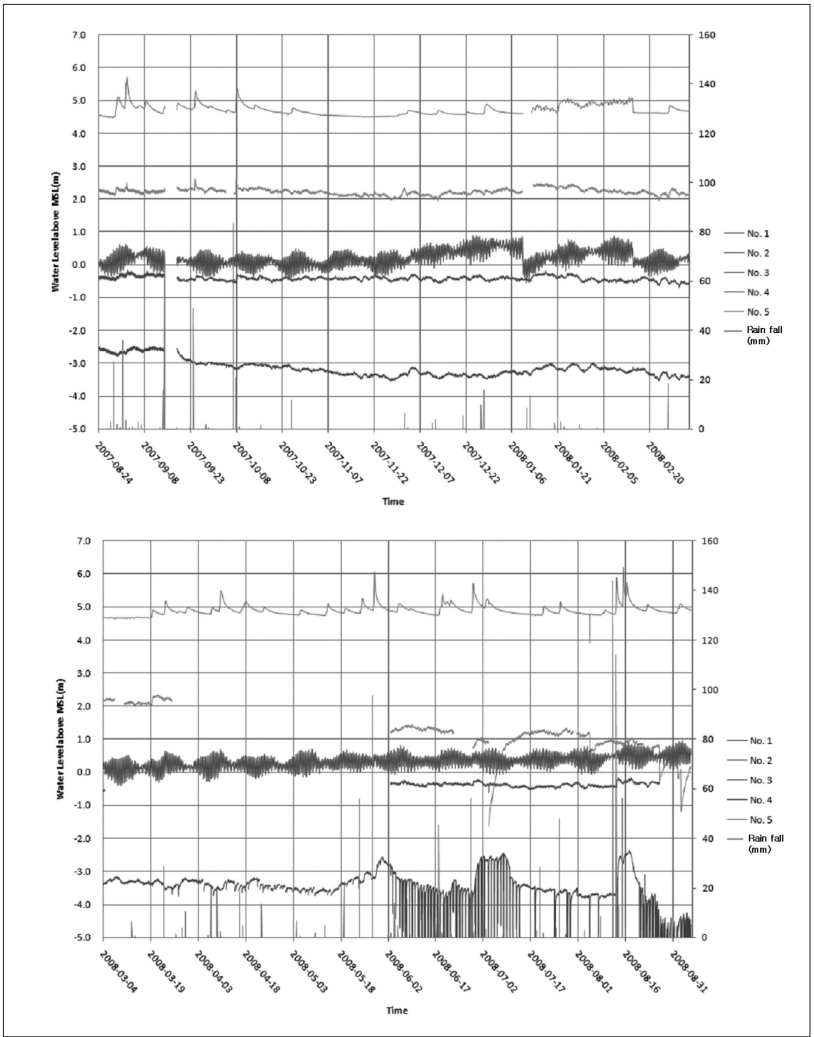

Fig. 3. Long-term variation of groundwater level by well $(2007.8 \sim 2008.8)$ [7]

\section{III. 모 델링}

\section{가. 모 델구성}

수치모의는 범용 지하수 모델링 프로그램인 MODFLOW [8]를 이용하여 수행하였다. 모델링 대상 지역은 고리 원자 력발전소와 봉화산 일부를 포함하는 $1,300 \mathrm{~m} \times 900 \mathrm{~m}$ 의 면 적을 갖는 영역으로 설정하였으며 전 면적을 $10 \mathrm{~m} \times 10 \mathrm{~m}$ 의 격자형 셀(grid cell)로 구획하였다(Fig. 4). 다만, 고리 1, 2 호기 및 상기 5 개의 관정을 포함하는 $560 \mathrm{~m} \times 440 \mathrm{~m}$ 의 면적 을 갖는 영역은 정밀 모델링을 위해 $5 \mathrm{~m} \times 5 \mathrm{~m}$ 의 격자형 셀 로 구획하였다(Fig 4의 작은 직사각형 지역). 정밀 모델링 지역을 제외한 나머지 부분은 비활성 이동 셀(inactive transport cell)로 지정함으로써 광역지역 지하수 유동 모델 결과로부터 구한 지하수 흐름을 그대로 정밀 모델링 영역에 적용할 수 있도록 하였다.

\section{나. 층(layer)}

건설 당시 지질도 및 지질단면도와 최근 설치된 5 개의 관정에서 얻은 시추자료에 근거하여 모델링 영역은 4 개의 수문지질학적으로 구분이 가능한 층으로 구성하였다. 즉, 상부부터 복토의 미고결층(Layer 1), 사암의 다공질 대수 층(Layer 2), 이암과 실트암의 불투수층(Layer 3) 및 유문 암의 암반층이다. 여기서 암반층은 발전소 구조물이 위치 한 상부의 암반층(Layer 4)과 하부의 암반층(Layer 5)으로 세분하였다(Fig. 5).

Layer 1은 복토구간(silty sand, sand)으로 수리전도도 값으로 문헌[9]에 보고된 값을 인용하여 $1.0 \times 10^{-3} \mathrm{~cm} / \mathrm{sec}$

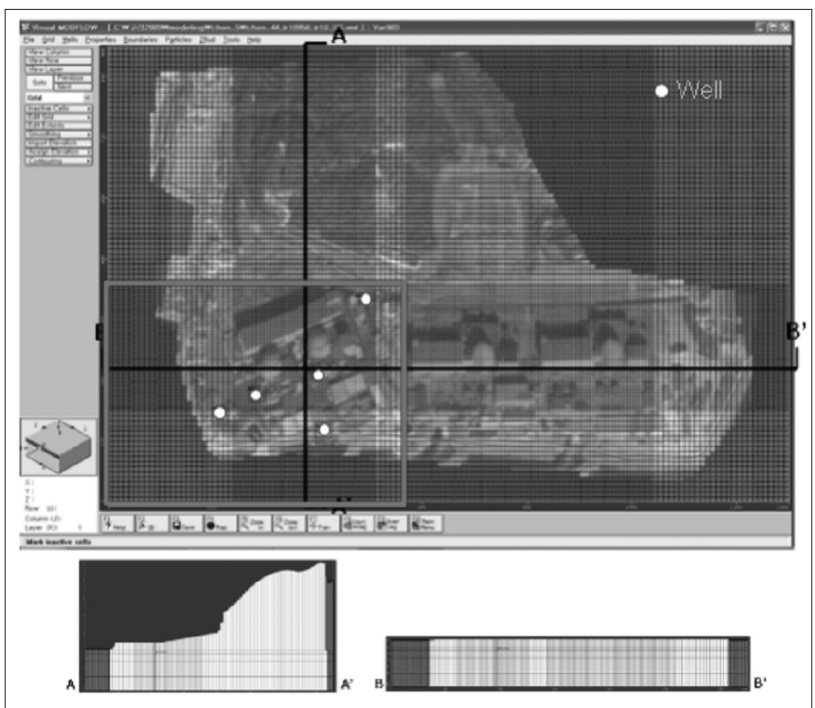

Fig. 4. Modeling area and cross-section (small rectangle shows detailed modeling area). 
$\left(\mathrm{K}_{1}\right)$ 을 적용하였고, Layer 2는 다공질층(사암)으로 2008 년 현장수리시험결과 가장 투수계수가 높았던 관측정 $\mathrm{NO}-3$ 의 수리전도도 $1.0 \times 10^{-4} \mathrm{~cm} / \mathrm{sec}\left(\mathrm{K}_{2}\right)$ 을 적용하였다. Layer 3은 불투수층(mudstone, siltstone)으로 수리전도 도값으로 현장 수리시험결과보다 다소 낮은 $1.0 \times 10$ ${ }^{6} \mathrm{~cm} / \mathrm{sec}\left(\mathrm{K}_{3}\right)$ 으로 설정하였다. Layer 4 와 Layer 5은 암반 층으로 수리전도도값으로 시추주상도에서 암반층을 대표 할 수 있는 관측정 NO-5의 수리전도도 $1.0 \times 10^{-5} \mathrm{~cm} / \mathrm{sec}$ $\left(\mathrm{K}_{4}, \mathrm{~K}_{5}\right)$ 을 적용하였다(Fig. 6).

모델링 대상 지역 북부경계는 등고선의 분수령(divide line)을 따라 무흐름경계(no-flow boundary)로 설정하였 으며, 해안선을 따라 EL 0 m의 고정수두경계를 Layer 1 Layer 5에 대해 설정하였다(Fig. 7). 또한 6개월의 건기 (2007.11 2008.4) 기간의 강수량에 함양율 약 $12 \%$ 를 적 용하였다(Fig. 7).

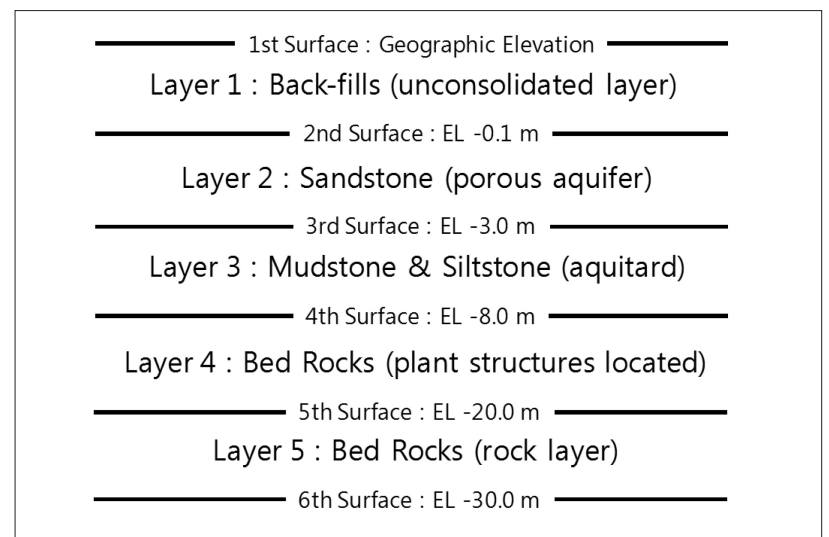

Fig. 5. Layer used in modeling.

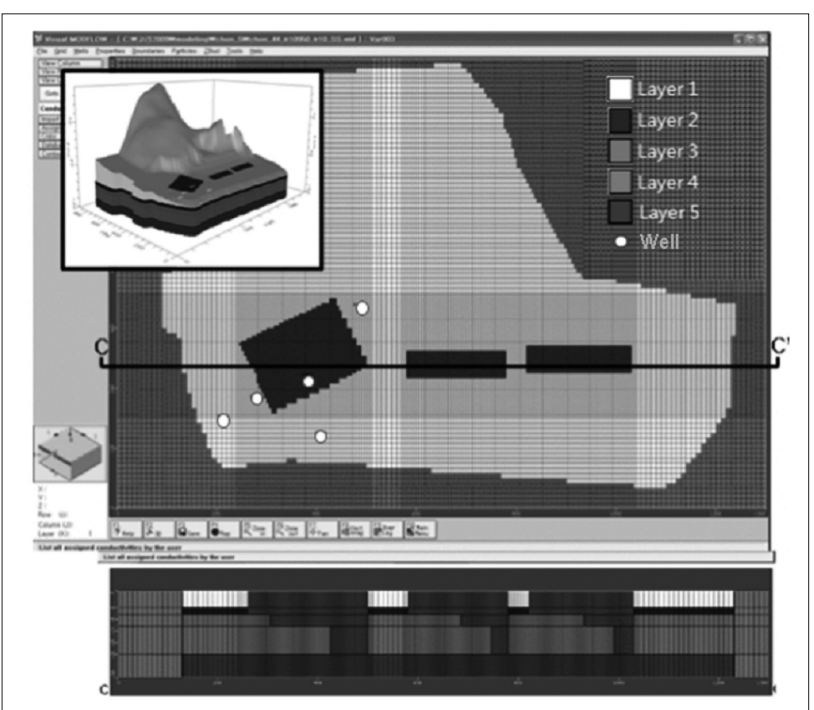

Fig. 6. Hydraulic conductivity zoning for each layer of modeling area and its $3 \mathrm{D}$ visualization.
지하수 수위 변화를 나타낸 Fig. 3에서, 관정 NO-2는 지 하집수조의 영향을 거의 받지 않고 강우에 의해서만 수위 가 변동되는 반면, 관정 NO-3의 경우는 강우에 의한 영향 은 거의 나타나지 않고 수위 관측기간 내내 지하수 수위가 해수면 이하로 유지되고 있음을 볼 수 있다. 이러한 사실 은 관정 NO-3의 경우 수위에 영향을 주는 다른 요인이 존 재하는 것을 의미하며 그 요인은 지하수 상승에 의한 발전 소 건물의 안정성 상실을 방지하기 위해 일정 수두 이상의 지하수를 펌프로 강제로 배출시키는 고리 2호기의 지하집 수조이다. 이를 반영하기 위해 Layer 1 Layer 4 에 대해 고리 2호기의 지하집수조 위치에 배수(drain)를 설정하였 다. 고리2호기의 지하집수조의 유입량이 200-700t/yr인 것 을 고려하여 모델보정을 통하여 컨덕턴스(conductance) 를 $12,000 \mathrm{~m}^{2} / \mathrm{day}$ 로 입력하였다. 지하수에 대한 영향이 미 미한 것으로 나타난 고리 1호기 지하집수조는 본 모델링 에서는 고려하지 않았다. 또한 고리 3, 4호기의 지하집수 조는 관련 자료는 없으나 전반적인 지하수 흐름에 영향을 줄 것으로 예상되기 때문에 Fig. 7과 같이 Layer 1 Layer 4 에 대해 배수를 설정하였다.

\section{다. 입자추적 및 오염운 거동}

지하수 유동을 가시화하기 위해 모델링 영역의 지하수 최 상류부와 고리 1,2 호기 구조물 북쪽 상류부에 가상의 입자를 설정하여 입자 이동 경로를 분석하였다(Fig. 8). 또한 가상의 누설 시의 삼중수소 오염운 거동을 장기 예측하기 위해 삼중 수소가 고리 1,2 호기 구조물 주변의 6개 점 누설원(point leak source)에서 사용후연료저장조 내 삼중수소 농도(1.35 $\left.\times 10^{-4} \mathrm{mg} / \mathrm{L}\right)$ 로 30 년간 지속적으로 누설되는 것으로 가정하 였다(Fig. 8). 이때 6 개의 점 누설원은 직사각형의 고리 1 발전

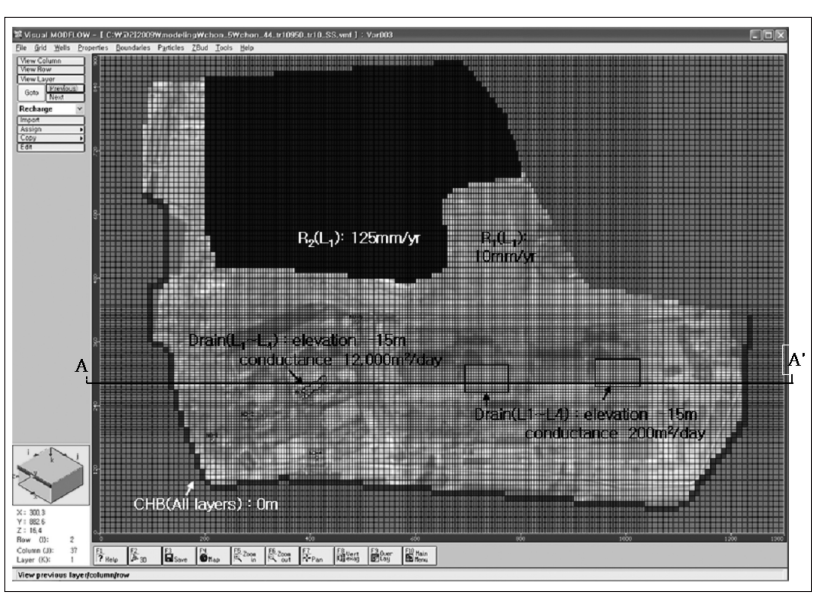

Fig. 7. Layout of constant head boundary( $($ ) , groundwater recharge( $\square)$, Drain $(\square)$ and cross-section. 
소 구조물이 위치한 부지 근처에서 발생하는 누설을 모사하 기 위해 선정되었다. 본 연구에서는 문헌[10]에 보고된 자료 를 이용하여 분산지수값에 대해 $10 \mathrm{~m}$ 의 값을 이용하였고, 용 질이동 모의시 삼중수소의 decay를 고려하여 반감기는 12.3 년을 적용하였다.

또한 지하집수조가 삼중수소의 오염운에 주는 영향을 알아 보기 위해 지하집수조가 존재하는 경우와 그렇지 않은 경우, 두 경우에 대해 모델링을 하였다. 오염운의 시간에 따른 변화 는 가상의 관정 OB-1과 OB-2(Fig. 8)에서의 지하수 내 삼중 수소의 예상 측정 농도로 평가하였다.

\section{IV. 결과 및 토의}

\section{가. 지하수 유동}

5개 관정의 건기(2007.11 2008.4) 6개월간의 평균 지하수 수위에 대한 정류상태 모델링에서 지하수수위자료, 수리시험 을 통한 수리전도도 $(\mathrm{K})$ 산정값, 지하집수조에서의 유입량 등 을 기준으로 보정한 결과 5 개 관정 모두의 평균 지하수 수위 가 도출된 검량선의 $95 \%$ 신뢰구간 내에서 만족하며 RMS가 $1.002 \mathrm{~m}$ 인 것으로 나타났다(Table 3). 이 검량선으로부터 구 한 각 층의 지하수 등위선은 대체적으로 서로 유사한 패턴을 보이나 발전소 구조물 부근에서는 조금 상이한 패턴을 보이 게 된다(Fig. 9). 즉, 산기슭에서는 대체로 유사한 등위선의 패턴을 보이던 각 층의 지하수 등위선이 발전소 구조물 주변

Table 3. Observed vs. Calculated Head.

\begin{tabular}{|c|c|c|c|}
\hline 관측정 & Observed Head $(\mathrm{m})$ & Calculated Head(m) & \multirow{2}{*}{ RMS (m) } \\
\cline { 1 - 3 } NO-1 & 0.02 & 0.61 & \multirow{2}{*}{1.002} \\
\cline { 1 - 3 } NO-2 & 2.67 & 1.13 & \\
\hline NO-4 & 0.69 & 1.09 & \\
\hline NO-5 & 5.20 & 6.27 & \\
\hline
\end{tabular}

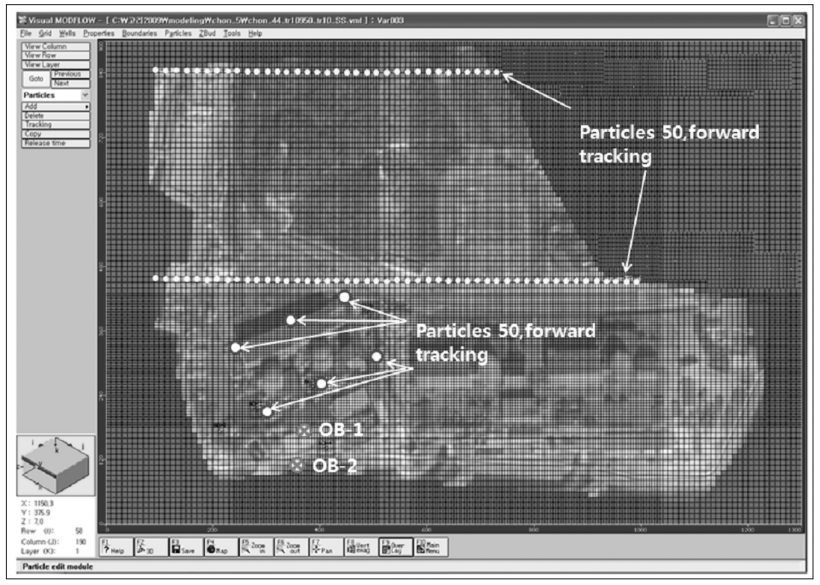

Fig. 8. Locations of point source leak, virtual Wells OB-1 and $\mathrm{OB}-2$ and results of particle tracking.
에서는 구조물을 중심으로 하는 원형의 패턴을 보이게 되는 데 이때 각 층의 깊이에 따라 그 원형의 패턴이 조금씩 다르 게 나타난다. 이러한 차이는 불투수성인 발전소 구조물의 형 상이 깊이에 따라 일정하지 않기 때문이며 또한 2호기 하부 에 존재하는 지하집수조로 인해 지하수 수위가 영향을 받기 때문이다.

또한 Fig. 9의 입자추적(particle tracking) 결과는 고리 1발 전소 부지 내 지하수의 주 유동방향은 남서방향이며 봉화산 기슭에서 발원하여 지하집수조로 유입되어 중간에 제거되는 일부를 제외하고는 모두가 바다에 도달하고 있음을 보여주고 있다. 즉, 최북단에서 유래된 입자의 일부가 구조물 내부로 이 동하여 지하집수조에 의해 양수되는 형상이 모든 층에서 보이 긴 하나, 대부분의 입자들은 고리 1,2 호기 주변에서 구조물 내부로 직접 이동하기보다는 그 주변을 따라 해안으로 이동하 는 하는 것으로 나타났는데 이는 구조물 외부(지하수 상류부) 에 위치한 대부분의 입자들은 구조물의 수리전도도가 매우 낮 아 지하집수조의 양수에도 불구하고 구조물 내부로 들어가지 못하기 때문이다. 지하수 하류부로 이동한 입자들 중 일부는 해안으로 이동하지 않고 양수의 영향으로 지하집수조 쪽으로 이동하는 경우도 있다. 한편 이러한 지하수의 이동은 대부분 수리전도도가 높은 Layer 1과 다공질 매질로 이루어진 Layer 2 를 통해서 이루어지고 있었으며 반면 투수성이 낮은 Layer 3 Layer 5 에서는 지하수 유속이 매우 느리게 나타났다.

\section{나. 삼중수소 오염운 거동}

고리 1,2 호기 구조물 부지 주변 6개의 점 누설원에서 삼중 수소가 1 년 및 30년간 누설된 상황을 모델링한 결과를 Fig. 10 및 Fig. 11에 각각 제시하였다. 두 그림 모두에서 삼중수소 의 오염운의 최종 도착지는 동쪽 및 남쪽의 해안이었으며, 초 기의 오염운의 분포는 대부분 얕은 층에 국한되다가 시간의 경과와 함께 깊은 층으로도 확대됨을 알 수 있었다. 이러한 오 염운의 거동은 삼중수소가 지하수의 성분으로 함께 이동되는 특성에 기인한다.

또한 오염운의 진행이 지하집수조에 의해 지연됨을 확인할 수 있었는데, 특히 Fig. 10에서 지하집수조가 없는 경우 삼중 수소의 오염운은 누설 시작 약 1 년 후 바다에 도달하는 반면 지하집수조가 있는 경우에는 그 보다 더 오랜 시간이 걸리는 것을 알 수 있었다. 다만, 누설 시작 30년 후를 모델링한 결과 는 나타낸 Fig. 11에서 지하집수조의 유무에 관계없이 삼중수 소의 오염운이 최종적으로는 바다에 도달한 결과로부터 지하 집수조는 삼중수소 오염운의 지연효과만 있을 뿐 차단효과는 없는 것을 알 수 있다. 


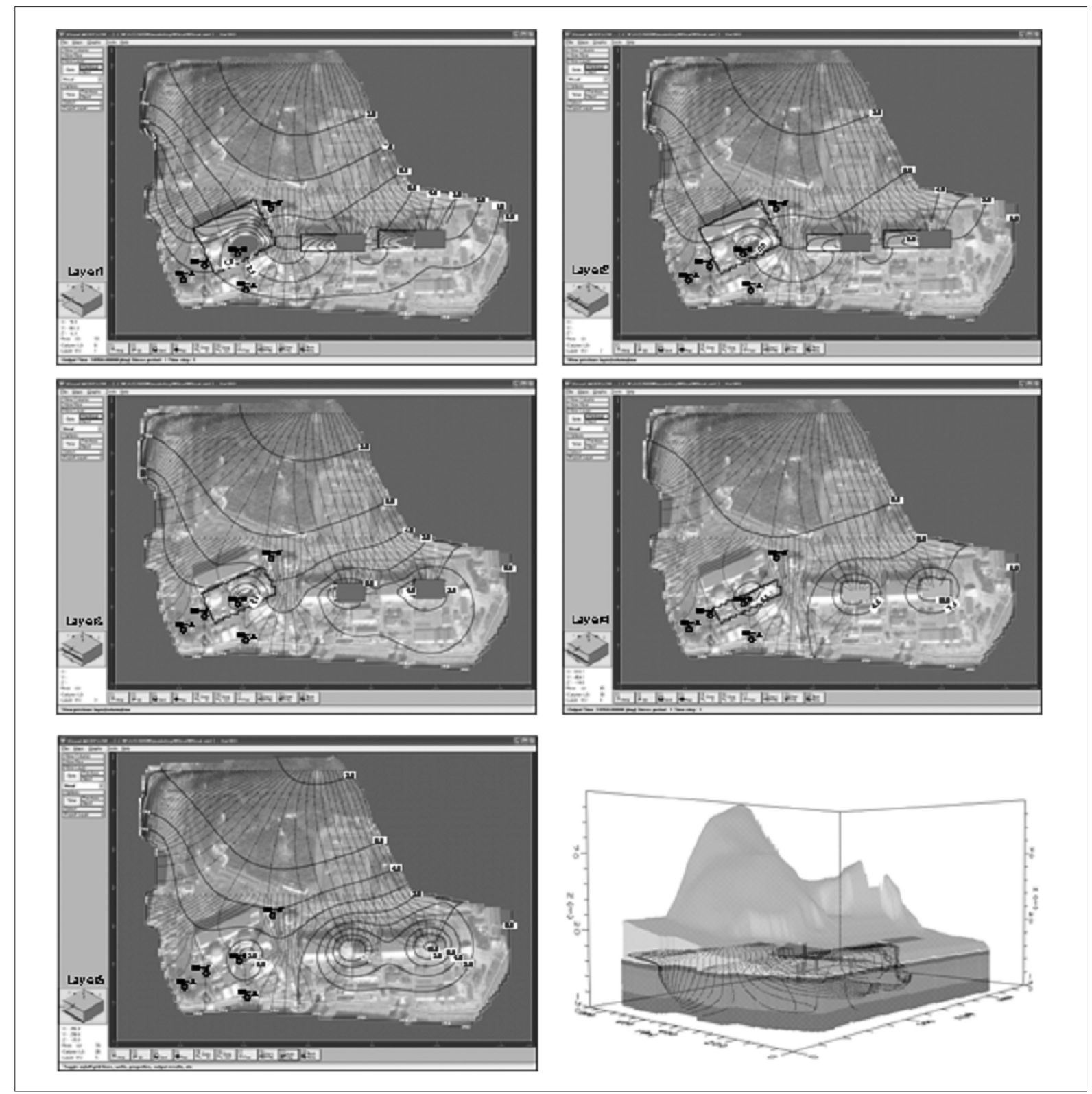

Fig. 9. Equi-potential line(blue line) and migration path of particles (brown line) according to groundwater flow by layer.

지하집수조의 지연효과를 정량적으로 알아보기 위해 시간 의 경과에 따른 가상의 관정 OB-1(발전소 및 바다 사이에 위 치) 및 OB-2(바다가에 위치)에서의 삼중수소 예상 농도를 계 산하였다(Fig. 12). 이 그림에서 각 관정에서 지하집수조가 없 는 경우가 있는 경우보다 삼중수소 농도의 상승속도가 더 빠 른 것을 알 수 있으며 또한 두 경우 모두에서 일정 농도 이상 이 되면 평형상태에 도달하여 더 이상의 농도 상승이 일어나 지 않음을 알 수 있다. 지하집수조가 있을 때와 없을 때 삼중 수소 농도가 미국 $\mathrm{EPA}$ 의 음용수용 지하수 중 삼중수소 농도 제한치 $(740 \mathrm{~Bq} / \mathrm{L})$ 에 도달하는 예상시간은 관정 $\mathrm{OB}-1$ 에서는
0.6 년 및 2.0년, 관정 OB-2에서는 3.4 년 및 9.8 년이었으며 따라서 관정 $\mathrm{OB}-1$ 에서는 1.4 년의, 그리고 관정 $\mathrm{OB}-2$ 에서는 6.4년의 지연효과가 각각 관찰되었다(Table 4).

Table 4. Expected time for groundwater tritium level to reach US EPA limit* for drinking water (unit: year).

\begin{tabular}{|c|c|c|}
\hline 관정 & OB-1 & OB-2 \\
\hline 모델링 조건 & 2.0 & 9.8 \\
\hline sump가 있는 경우 & 0.6 & 3.4 \\
\hline sump가 없는 경우 &
\end{tabular}

* US EPA Maximum Contaminant Levels (MCL) of tritium for drinking water $=740 \mathrm{~Bq} / \mathrm{L} \fallingdotseq 2.08 \times 10^{-9} \mathrm{mg} / \mathrm{L}$ 


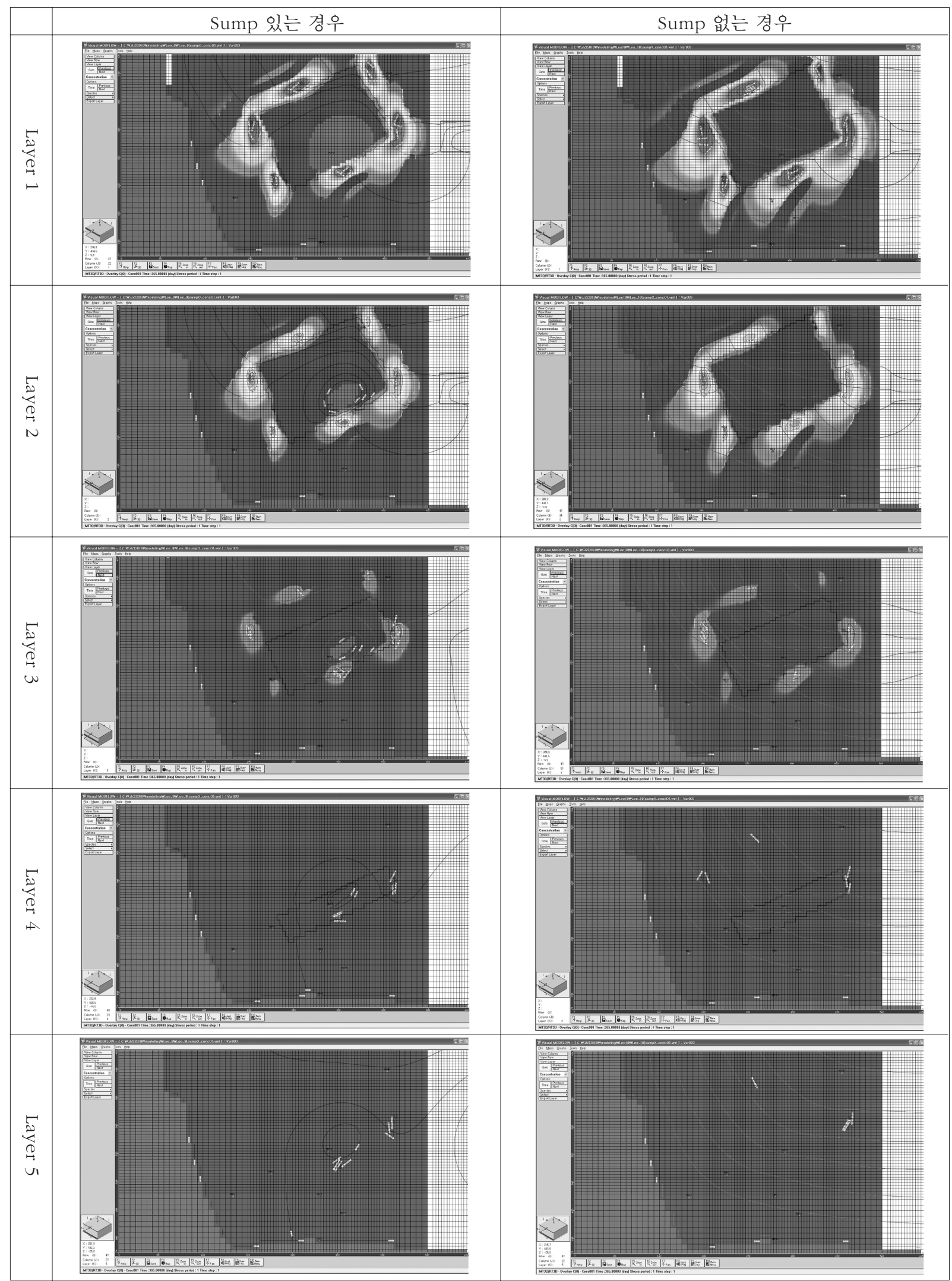

Fig. 10. Behavior of contamination plume in 1 year after initiation of leak. 
Groundwater Flow and Tritium Transport Modeling at ...

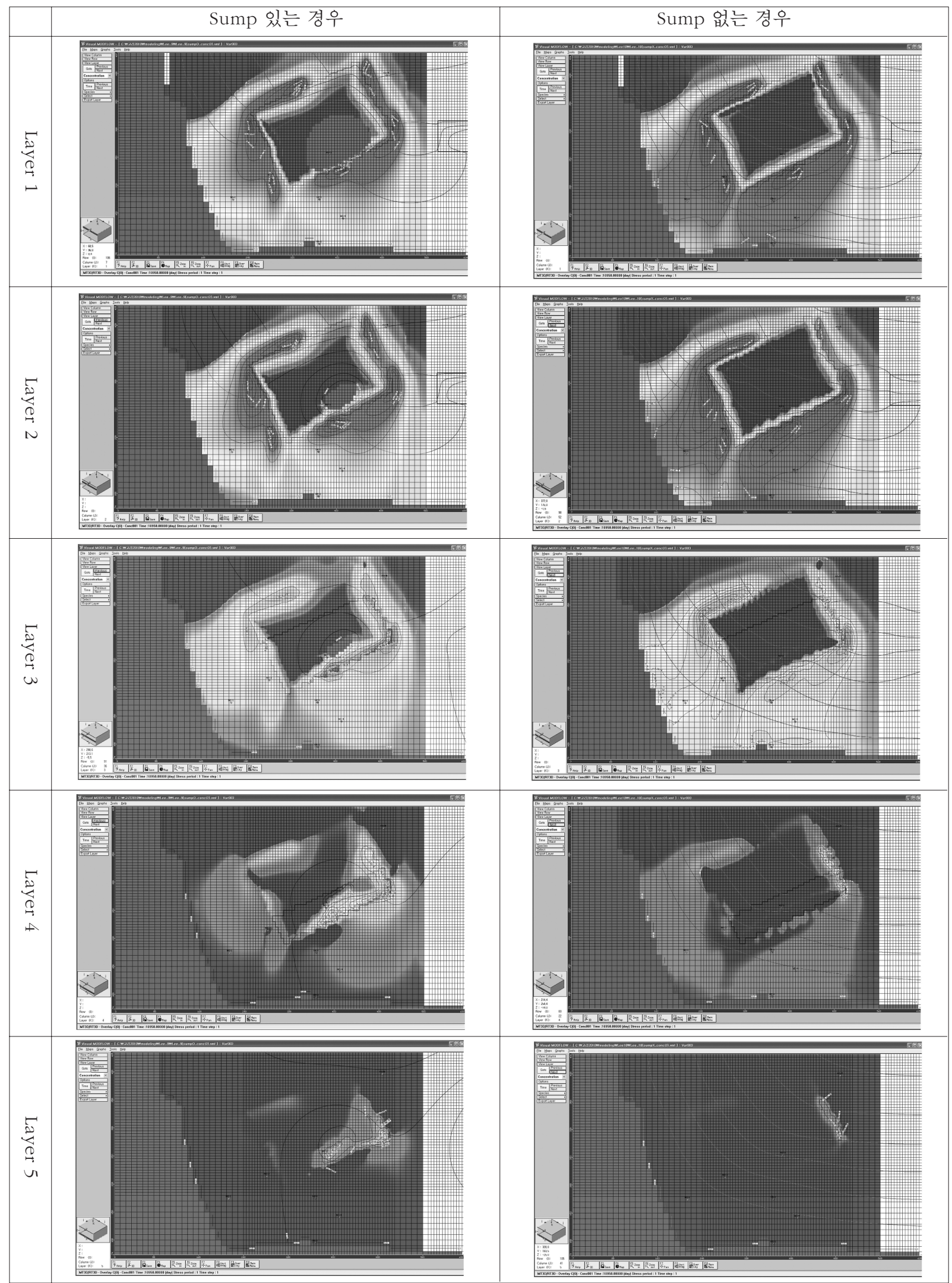

Fig. 11. Behavior of contamination plume in 30 years after initiation of leak. 


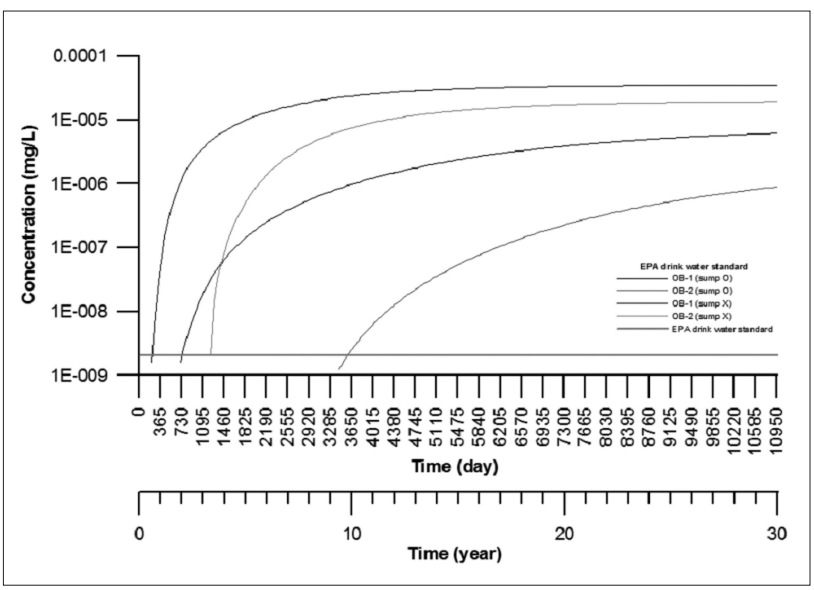

Fig. 12. Variation of tritium concentration at virtual Wells $O B 1$ and $\mathrm{OB} 2$ based on leak scenario.

\section{V. 결 론}

고리 1 발전소 부지 내 지하수 특성에 대한 조사 결과, 부지 내 지하수는 발전소 배후의 산기슭에서 발원하여 부지에 유입 된 후 2호기 지하집수조에 의해 중간에서 제거되는 일부를 제 외하고는 모두가 바다에 도달하는 것으로 나타났다. 고리 1 발 전소 건물 주변에 6 개의 가상의 점 누설원에서 지속적적으로 삼중수소가 누설되는 상황을 가정하여 삼중수소의 오염운 거 동을 모델링한 결과, 지하집수조가 삼중수소 오염운이 바다에 도달하는 것을 차단하지는 못하였으나 어느 정도 지연하는 효 과가 있는 것으로 나타났다.

상기 모델링의 결과로부터, 고리 1 발전소의 경우 대부분의 지하수의 최종 도달 지점이 바다이기 때문에 비계획적 방출의 조기 감시를 위해서는 누설 가능성이 있는 계통 및 기기와 해 안가 사이에 관정을 설치하는 것이 바람직하며, 현재 운영 중 인 관정의 대부분은 이러한 목적에 적합한 위치임을 확인하였 다. 또한 광범위한 지역의 지하수가 유입되는 지하집수조를 지하수 감시용으로 활용함으로써 보다 효과적이며 경제적인 지하수 감시가 가능할 것으로 기대되었다. 다만 대중에 대한 신뢰성 확보 측면에서 부지경계에 관정을 설치하여 부지 외로 삼중수소가 이동하지 않음을 보여줄 필요도 있다. 한편, 고리 1 발전소의 경우 대부분의 지하수가 바다로 향하기 때문에 비 계회적 방출 발생으로 인해 추가적인 주민 피폭 경로는 발생 하지 않는 것으로 확인되었다.

고리 1 발전소 지하수 감시 프로그램 수립과 관련하여 다음 과 같은 사항이 고려되어야 한다.

첫째, 지하수 흐름에 대한 모델링 결과, 지하집수조에 의해 중간에 제거되는 일부를 제외하고는 모든 지하수가 동쪽 및
남쪽의 해안으로만 도달하고 육상의 다른 발전소 경계로는 이 동하지 않는 만큼, 지하수 감시를 위한 관정은 발전소 내 누설 가능성 있는 계통 및 기기의 지하수 하류방향, 즉 바다방향으 로만 설치해도 충분히 비계획적 방출을 조기에 감시할 수 있 을 것으로 생각된다. 현재 고리 1발전소에 설치된 관정 NO-1 $\sim \mathrm{NO}-4$ 는 이러한 목적에 부합된다고 판단된다. 다만, 해외의 사례에서도 비계획적 방출에 대한 사회적 민감성을 고려할 때, 대중에 대한 신뢰성 확보 차원에서 부지 경계에 관정을 설 치하여 삼중수소가 부지 외로 이동되지 않음을 객관적으로 보 여줄 수 있는 자료를 확보하는 것이 필요할 것으로 판단된다.

둘째, 일부 지하수가 유입되는 지하집수조의 역할에 주목 할 필요가 있다. 즉 지하집수조는 넓은 지역에 분포하는 지하 수를 양수함으로써 삼중수소 오염운의 진행을 지연시키는 긍 정적인 효과가 있을 뿐만 아니라 그 자체가 지하수를 감시할 수 있는 지점으로 활용할 수 있다. 지하집수조는 유입되는 지 하수 범위가 광범위하므로 좁은 지역에 분포하는 지하수에 대한 감시가 가능한 일반 관정과 달리 광역의 지하수 오염 감 시에 더 효과적으로 사용할 수 있으며, 이를 통해 관정 설치의 수를 줄일 수 있을 것으로 기대된다.

셋째, 원전 주변 주민의 피폭에 대해 다음과 같이 생각할 수 있다. 지하집수조에 모인 지하수도 결국은 계획적 방출에 의 해 바다로 방출되므로 부지 내 흐르는 모든 지하수의 환경에 의 최종 방출지점은 바다로 생각할 수 있다. 또한 현재 고리 1 발전소 부지 내에서 지하수는 음용수로 사용되지 않는다. 따 라서 오염된 지하수의 환경 방출에 의해서 수영, 해상활동 및 해산물 섭취 등의 기존 경로 외에 새로 추가되는 경로는 없는 것으로 판단되었다.

마지막으로 금번 모델링은 기존의 수문지질조사 및 각종 관련 자료의 조사를 통해 수행되었으나 수집된 자료의 불충 분으로 모델링의 정밀도 및 정확도는 추후에 향상의 여지가 있으며 이를 위해서는 추가 관정의 설치 및 지중매설 배관의 검사 등의 반복 추가 자료조사 그리고 고리 2 발전소 부지의 수문지질학 조사를 포함한 추가적인 조사가 필요하다.

\section{참고문헌}

[1] S. Richards, T. Frye, J. Shepherd, T. Nicholson, G. Kuzo, U. Shoop, S. Sakai, R. Allen, Liquid Radioactive Release Lessons Learned Task Force Final Report, US Nuclear Regulatory Committee (2006).

[2] Nuclear Energy Institute, Industry Ground Water 
Protection Initiative - Final Guidance Document (2007).

[3] 최병영, 김건영, 고용권, 신선호, 유시원, 김두행, "중 저준위 방사성 폐기물 처분부지의 지구화학 특성 I. 지 하수", 방사성폐기물 학회지, 6(4), pp.297-306 (2008)

[4] 박경우, 지성훈, 고용권, 김건영, 김진국, "중·저준위 방사성폐기물 처분 부지의 지하수 유동에 대한 수치 모 사: 2. 처분 안전성 평가 인자", 방사성폐기물 학회지, 6(4), pp.283- 296 (2008).

[5] 박경우, 지성훈, 김천수, 김경수, 김지연, "중·저준위 방사성폐기물 처분 부지의 지하수 유동에 대한 수치 모 사: 1. 지하수 유동 모델링" ,방사성폐기물학회지, 6(4), pp.265-282 (2008).

[6] 지오텍컨설탄트, 한국전력기술, 고리 1호기 지하수 관 측시설 설치 및 지하수 분포/수문학적 특성평가, 한국 수력원자력 (2008).

[7] 손욱, 손순환, 고리 1,2 호기 부지의 수문지질 및 지하 수 거동 규명을 통한 오염물질 이동 특성 평가, 한전 전력연구원 (2009).

[8] Harbaugh, A. W., Banta, E. R., Hill, M. C., and McDonald, M. G. (2000). MODFLOW -2000, the U. S. Geological Survey modular ground-water model? User guide to modularization concepts and the Ground-Water Flow Process. Open-File Report 00-92. U. S. Geological Survey.

[9] R.A Freeze and J.A Cherry, Groundwater, p.604, Prentice Hall, Englewood Cliffs (1979).

[10] Schulze-Makuch, D. (2005). Longitudinal dispersivity data and implications for scaling behavior, Ground Water, vol.43, no.3, pp.443-456. 